Estuarine, Coastal and Shelf Science

September 2015, Volume 162, Pages 45-52

http://dx.doi.org/10.1016/j.ecss.2015.03.033

http://archimer.ifremer.fr/doc/00257/36817/

(c) 2015 Published by Elsevier Ltd.

\title{
Response of diatom and dinoflagellate lifeforms to reduced phosphorus loading: a case study in the Thau lagoon, France
}

\author{
Gowen R.J. ${ }^{1,}{ }^{*}$, Collos Yves ${ }^{2}$, Tett Paul ${ }^{3}$, Scherer $C^{1}$, Bec B ${ }^{2}$, Abadie Eric ${ }^{4}$, Allen $M^{5}$, O'Brien ${ }^{6}$
}

${ }^{1}$ Fisheries and Aquatic Ecosystems Branch, SAFSD, Agri-Food and Biosciences Institute, Belfast BT9 5PX UK

${ }^{2}$ Université de Montpellier, CNRS, IRD, IFREMER, UMR 9190, MARBEC, CC093, 34095 Montpellier

Cedex 5, France

${ }^{3}$ Scottish Association for Marine Science, Scottish Marine Institute, Oban, Argyll, PA37 1QA, UK

${ }^{4}$ Ifremer, Laboratoire Environnement Ressources, CS30171, 34203 Sète, France

${ }^{5}$ Biometrics Information \& Systems Branch, FCAD, Agri-Food and Biosciences Institute, Belfast, BT9 5PX, UK

${ }^{6}$ National Marine Fisheries Service, NOAA, Silver Spring, Maryland USA

* Corresponding author : R.J. Gowen, email address : richard.gowen@afbini.gov.uk

\begin{abstract}
:
The basin of Thau in southern France is a shallow, weakly flushed lagoon which is an important location for oyster cultivation. Phytoplankton analyses were carried out in 1975-1976 and then (almost) continuously since 1987. We report an investigation of 'the balance of organisms' in phytoplankton in relation to reductions in phosphorus loading, using two new tools based on phytoplankton lifeforms: the Plankton Index for Phytoplankton (PIp); Euclidean distance in state space. Our results show the utility of the tools for analysing changes in the „balance of organisms" at the level of functional groups (in our study diatoms and dinoflagellates), but also illustrate the difficulties in demonstrating the reversal of human impacts resulting from eutrophication.
\end{abstract}

The comparison between 1987-89 and 1976 showed the expected 'de-eutrophication' due to the reduction in dissolved inorganic phosphate (DIP), with a decrease in dinoflagellate abundance. Since 1989, year-to-year variation in annual mean concentrations of (DIP) may have contributed to interannual variability in the balance of the two lifeforms, but the data suggest that the system has remained in a dynamically stable regime because: (i) there was no long-term trend in Euclidean distance from the reference; and (ii) there was no increase in inter-annual variability about the time-series mean Euclidean distance suggesting there has been no decrease in resilience which might signal a regime change.

Integrated management of human activities will be required to manage (and reduce) total $P$ in the system. Monitoring phytoplankton and nutrients concentrations to determine how primary production and the balance of species respond to further changes in the nutrient status of the lagoon should be an integral part of any management programme. 
Keywords : Eutrophication, Thau lagoon, phosphorus, lifeform, state-space, Euclidean distance

\section{Introduction}

Marine eutrophication is considered a recent problem (Nixon, 1995) but one that can potentially impact coastal water bodies world-wide and is of increasing severity (Mclntyre, 1995). There is evidence that anthropogenic nutrient enrichment of some northern European coastal regions has increased phytoplankton biomass and production (Radach et al., 1990; Schaub and Gieskes, 1991; De Jonge et al., 1996; Gowen et al., 2000; Andersen et al., 2011; EErtebjerg et al., 2001; Conley et al., 2002; Rousseau et al. eds, 2006). Cloern (2001) argued that coastal eutrophication involved more than the stimulation of primary production because the input of nutrients to coastal water bodies can disrupt the balance between the production and turnover of organic matter and alter the seasonality of ecosystem functions. Also of concern are changes in the floristic composition of the phytoplankton (Gillbricht, 1988; Lancelot et al., 2006) that can result in: "visible algal blooms, algal scum" (Vollenweider, 1992); "the presence of noxious phytoplankton and bottom water anoxia" (Justic et al., 1995); the occurrence (including an increase in frequency, size and duration) of harmful algal blooms as has been the case in the Seto Inland Sea of Japan and Tolo Harbour, Hong Kong (see Gowen et al., 2012A and references cited therein).

In many countries, legislation has been introduced to mitigate anthropogenically driven coastal eutrophication. In addition to national legislation, the 28 member states of the European Union are subject to EU directives. In 2004, the European Court of Justice ruled (Case C-280/02: http://curia.europa.eu) that the „Thau lake", a shallow lagoon in southern 
France, should be 'identified as an area sensitive to eutrophication within the meaning of Directive 91/271' (the Urban Waste Water Treatment Directive, CEC, 1991). This directive (see also Ferreira et al., 2011) defines eutrophication as a process culminating in an undesirable disturbance to the balance of organisms and to the quality of the water concerned. Stimulation of the growth of one or more phytoplankton species is considered a disturbance and that of a nuisance or harmful species undesirable. However, the populations of species that make up the phytoplankton are not constant in time or space (Gowen et al., 2012B) and against this background of natural variability, quantifying a disturbance to the balance of organisms is not a trivial task.

The Thau lagoon is a small $\left(75 \mathrm{~km}^{2}\right)$ marine lagoon located on the French Mediterranean coast (Fig. 1). The lagoon is shallow (mean depth $4 \mathrm{~m}$ ) and is connected to the sea by 3 narrow channels. Approximately 10\% of French oyster (Crassostrea gigas) production takes place in the lagoon. Picot et al. (1990) reported the production to be 20,000 tonnes per year. A number of studies suggest that the lagoon is a predominantly nitrogen $(\mathrm{N})$ limited system (Collos et al., 1997; Souchu et al., 1998, 2001; Bec et al., 2005). There is an input of N via freshwater inflow during the winter which supports phytoplankton growth and sometimes leads to DIP limitation (Collos et al., 2014), but during the spring and summer the input of $\mathrm{N}$ via freshwater inflow is low. The nutrient dynamics of the lagoon are complicated by anoxic events which promote the sediment efflux of nutrients which support enhanced phytoplankton production. During one such event during the summer of 1994, Souchu et al. (1998) measured maximum bottom water concentrations of $24 \mu \mathrm{M}$ ammonium $\left(\mathrm{NH}_{4}\right), 5 \mu \mathrm{M}$ (DIP) and $57 \mu \mathrm{M}$ silicate (Si). Phytoplankton biomass measured as chlorophyll concentration reached 10 and $15 \mathrm{mg} \mathrm{m}^{-3}$ in surface $(1 \mathrm{~m})$ and bottom $(8 \mathrm{~m})$ water respectively. 
Since the 1960s there has been a programme to reduce anthropogenic waste input to the lagoon. A gradual increase in the number of houses connected to waste water treatment culminated in approximately 95\% of houses in the catchment having been connected by 1990 (La Jeunesse and Elliott, 2004). Collectively, the installation of a waste water treatment plant for the city of Sète in 1972 (designed to divert waste water from the lagoon), the introduction of activated sludge treatment between 1975 and 1987 and the establishment of a French national limit on phosphorus $(\mathrm{P})$ in detergent in 1990, have contributed to the reduction in $\mathrm{P}$ loading to the lagoon (Souchu et al., 1998, La Jeunesse and Elliott, 2004). Water-column concentrations of DIP have decreased by $90 \%$ between 1971 and 1994 (La Jeunesse and Elliott, 2004). The reductions in domestic $\mathrm{N}$ and $\mathrm{P}$ loading were expected to have brought about a reduction in bacterial biomass and anoxic events (which caused mortality of oysters) in the Thau lagoon. Thirty years later, that particular goal was reached (Souchu et al., 1998), but one unexpected consequence was the emergence of picocyanobacteria and the toxic dinoflagellate Alexandrium catenella (Collos et al., 2009).

In this paper we report an investigation of this 'balance of organisms' using two new tools. One tool, the Plankton Index for Phytoplankton (PIp) is derived from the Phytoplankton Community Index of Tett et al. (2008). The second involves the calculation of Euclidean distance in state space (Tett et al., 2013). There are few records of phytoplankton composition before nutrient enrichment of the lagoon and so we did not initially hypothesize what the 'natural balance' would be. Instead, the study focussed on changes over the period of data availability.

\section{Methods}

\subsection{Data sets}


The data sets used in the study are summarised in Table 1. Diatom and dinoflagellate abundance data were taken from phytoplankton counts from Hénard (1978) for the years 1975-1976 and from the French REPHY monitoring programme:

(http://envlit.ifremer.fr/surveillance/phytoplancton_phycotoxines) from 1987 and onwards. Annual mean water temperature and DIP concentrations are from Souchu et al. (1998), Collos et al. (2009) and from the REPHY monitoring programme. Annual mean concentrations of DIP were derived from monthly values. The silicate data are from: http://envlit.ifremer.fr/documents/bulletins/rno and the oyster data from Deslous-Paoli et al. (1998).

Regular phytoplankton analyses were carried out in 1975-1976 and after a 10 year gap almost continuously since 1987. Both the Plankton Index for Phytoplankton and the Euclidean distance tools require a reference condition which should ideally include several years, to account for the short-term inter-annual variation, so we chose the first three years (1987-89) of the continuously-sampled period. This allowed us to make: (i) a backwards comparison with the 1970s data; (ii) a forward comparison with more recent data (1990 to 2009) to identify any trend in the more recent data.

\subsection{Lifeform and state-space tools}

The concept of phytoplankton lifeforms was developed by Margalef (1978) (see also Pingree et al., 1978; Bowman et al., 1981; Jones and Gowen, 1990), with each lifeform being considered a different set of acclimations/adaptations to survival in a turbulent environment. This is a perspective that starts from species, but recent ecological theory (Folke et al., 2004; Hooper et al., 2005) is tending to the view that it is functional diversity rather than species diversity that underpins the operation and resilience of ecosystems. Lifeforms are, in 
principle, units of ecosystem functional diversity and a lifeform can be defined as: a group of species (not necessarily taxonomically related) that carry out the same important functional role in the marine ecosystem. Monitoring changes in lifeform abundances thus provides a means to monitor changes in the organization of plankton communities which in our opinion should be taken into account when assessing the response of the planktonic component of the pelagic ecosystem to anthropogenic pressure. The term `organization' derives from Costanza (1992) and Mageau et al. (1995), who use it to label the trophic and biogeochemical connections amongst ecosystem components, in distinction from 'vigour', the flow of energy and materials through ecosystems that maintains their organization. In the case of terrestrial and benthic communities, spatial arrangements should, we think, be seen as part of organization; in the case of pelagic communities, we consider that the seasonal succession of lifeforms makes an analogous contribution and so needs to be taken into account by methods for tracking change in ecosystem state.

Based on General Systems Theory (von Bertalanffy, 1968), Tett et al. (2008) proposed to track changes in the state of the phytoplankton community by means of plots in a state-space and calculating a Plankton Community Index (referred to here as a Plankton Index, PI). The conceptual framework (Tett et al., 2013) is that ecosystems can be viewed as systems with an instantaneous state defined by values of a set of system state variables which are attributes of the system that change with time in response to each other and external conditions. Our method assumes that the abundances of lifeforms of pelagic micro-algae are suitable variables to provide coordinates that define system state in multi-dimensional 'lifeform state space', and in principle, the mathematical treatments that we use can be generalised to multiple dimensions. In practice, it is difficult to visualise graphs in more than 3 dimensions, 
and so we suggest the use of 2-D plots leading to values of Plankton Indices that can be combined by simple averaging.

In the present work, we use the abundances of two lifeforms, diatoms and dinoflagellates, to define axes in a state space of 2 dimensions, corresponding to a Cartesian co-ordinate system in which each point in a plane is specified uniquely by a pair of numerical coordinates. The main genera and species (and size ranges) that make up the two lifeforms are given in Table 2. Matlab ${ }^{\mathrm{TM}}$ scripts with accessory functions were written to generate the state space plots and calculate values of (in this case) the Plankton Index for phytoplankton (PIp). An ecosystem state can be defined as a single point in state-space, with co-ordinates provided by the values of the set of state variables - i.e. by lifeform abundances. A trajectory connects two or more points. Such trajectories often show three components of variability: (i) cyclic; (ii) medium-term; and (iii) long term. In the case of temperate latitude plankton, the first can be interpreted as seasonal variation and thus as part of community organization. Both (i) and (ii) can be seen in terms of systems theory as movement around an attractor or within a basin of attraction (Holling, 1973) corresponding to a particular regime (or group of states and trajectories) of the ecosystem. Long term variability may show a persistent trend of movement away from a starting point in state space.

Given the seasonal nature of plankton production and the succession of species, and assuming approximately constant external pressures, the data collected from a particular location over a period of years forms a cloud of points in state-space; a regime. Such regimes can be defined by drawing an envelope around the group of points, using a convex hull method (Sunday, 2004; Weisstein, 2006). Because of theoretical arguments (see Tett, 2014) that the envelope 
should be 'doughnut' shaped with a central hole, bounding curves can be fitted outside and inside the cloud of points.

Both the Plankton Index and the Euclidean distance (see below) tools require a reference condition against which change can be quantified. This should ideally include several years of data to account for short-term inter-annual variation. Here the term 'reference' is used simply to denote the data set against which comparisons will be made and does not imply pristine conditions. Tett et al. (2008) found that the size and shape of the envelope was sensitive to sampling frequency and the total numbers of samples. Large envelopes generated by including extreme outer or inner points are less sensitive to change in the distribution of points in state space and therefore to detecting a change in condition. Conversely, if the envelope is made smaller by excluding too many points, even minor changes will be statistically significant. We decided to include a proportion $(p=0.9)$ of the points, with $5 \%$ of points that were most distant from the cloud's centre, and 5\% of points that were closest to the centre excluded.

The index is based on a comparison between the reference envelope and a new set of data by plotting the latter onto the reference envelope and is calculated as the ratio of new points inside the envelope (or to be precise, between the inner and outer envelopes) to the total number of new points. The maximum value of the index which can be calculated is 1 , which indicates no change. The minimum value, 0 , indicates a complete change (i.e. all new points fall outside of the reference envelope). In fact, since the reference envelope included only proportion $\mathrm{p}$ of the reference data, a PIp value of $p$ also indicated no change. Statistical significance was assessed by an exact binomial calculation of the probability of getting a value of the PIp given $\mathrm{n}$ (new points) and $p$. The software and mode details of the method are 
available from: www.sams.ac.uk/paul-tett.

For the backwards comparison 22 new points were compared with the reference envelope. Forward comparisons, between the reference period and data collected between 1990 and 2009, was made by re-plotting the reference envelope and adding new points (n) for each year of data, to calculate a value of the index for each year and generate a time-series.

\subsection{The Euclidean distance method}

The state-space approach was also used for an Euclidean distance method, which provided a means of quantifying system variability as well as estimating a trend away from a starting point in state space. The Euclidian distance is a positive scalar, the square root of the sum of squares of movement along each axis of the state space. Logarithmic transformation of the original co-ordinates avoids the calculated distance being dominated by any one axis. The conceptual framework for this method was presented by Tett et al. (2013) and is based on Scheffer et al. (2009) and Scheffer (2010) who proposed that increased variability was a sign of decreasing system resilience, and would thus give an early warning of a regime shift. Tett et al. (2013) suggested that an ecosystem close to a regime shift could be viewed as being pulled in several directions by 'attractors' for the old and new regimes, hence the increase in variability as a tipping point was approached; they suggested using medium-term variability as a proxy for (inverse) resilience.

We applied this method to the 1988-2009 data from the Thau lagoon. The annual median (base 10 logarithmic) abundance of each lifeform was plotted in 2-D state space, and a timeseries was calculated of the Euclidean distance of each annual median from the 1987-1989 reference point in state space. Like Tett et al. (2013), we evaluated medium-term variability 
as the scatter of annual values of the distance about a low-order polynomial fitted to the Euclidian distance time-series.

\subsection{Time-series and cross correlation analysis}

Each time series was screened for autocorrelation and where necessary an appropriate model applied to induce stationarity before cross-correlating to detect significant lags. If a model was applied to a time series prior to cross-correlation, the model's residuals were used in the cross-correlation analysis. The Mann-Kendal (M-K) test for monotonic trends (Hirsch and Slack, 1984) and regression analysis were applied to the raw data. For the latter, year and year $^{2}$ were fitted as the explanatory variable and the Thau lagoon time series as the response, to detect linear and non-linear trends, respectively. The regression residuals were assessed for non-normality and stationarity. The Run's Test for Randomness was applied to each time series to assess if the time series was randomly fluctuating about the mean of the time series.

For the forward comparison between the reference data with more recent data, PIp (the output time series), was cross-correlated with the pressure variables (the input time series), to detect lagged responses. Cross correlation was based on year-to-year variation and not on long-term trends. It was assumed that the relationship was one-sided and feedback mechanisms were not investigated.

\section{Results}

The time-series of annual mean water temperature and oyster biomass were non-stationary. Stationarity was induced by applying an auto-regression AR(1) model to the temperature data and an $\mathrm{AR}(2)$ model to the Oyster biomass data before further analysis. The time-series on 
annual median DIP concentration was stationary. There were too many gaps in the silicate time-series for analysis, although the data suggest that there has not been a long-term change in the concentration in the lagoon (Fig. 2D). For the other three variables, there were significant trends in the time-series: non-linear for annual mean water temperature and oyster biomass and linear for the annual mean concentration of DIP. Annual mean water temperature increased from $14.8^{\circ} \mathrm{C}\left(1974-1976\right.$ mean) to a $2008-2010$ mean of $15.6^{\circ} \mathrm{C}$. The annual mean concentration of DIP and concentrations from which annual means were derived are shown in Figure 2B. The annual mean decreased from a 1975-1976 value of $2.96 \mu \mathrm{M}$ (range $0.66-7.92 \mu \mathrm{M}, \mathrm{n}=24$ ) to a mean $1987-1989$ concentration of $1.51 \mu \mathrm{M}$ (range 0.20$2.80 \mu \mathrm{M}, \mathrm{n}=27$ ) and a 2002-2003 mean concentration of $0.47 \mu \mathrm{M}$ (range $0.08-0.86 \mu \mathrm{M}, \mathrm{n}=$ 21) Over the time-series, oyster biomass increased from a mean (1970-1972) stock of 2300t to a maximum of $19,000 t$ in 1987 . Thereafter, biomass was $12,500 t$ (mean 1999-2001). No significant (year-to-year) cross correlations between the PIp and annual mean water temperature or oyster biomass were identified, but the correlation between the PIp and annual mean DIP was significant $(P<0.05)$ with a positive lag of zero.

For the backwards comparison between the reference period and eutrophic conditions of the 1970s, the 2-D diatom and dinoflagellate state space plot was constructed for the reference years 1987-1989 (Fig. 3A). In Figure 3B, the 1970s data were plotted onto the reference plot and showed that dinoflagellate abundance was much higher in the1970s. The two data sets were significantly different (binomial probability $P<<0.001$ ). For the forward comparison, between the reference conditions and data collected between 1990 and 2011, the index appeared to show a downward trend (Fig. 4). However, time-series analysis showed that this was not significant and annual values fluctuated randomly (Run's Test: $P>0.05$ ) about the time-series mean value of 0.62 . 
Plotting annual median values of each lifeform in diatom-dinoflagellate state space (Fig. 5) shows that there was considerable inter-annual variability. For example, the co-ordinates for 1993 approached those for 1975/1976 and the years 1997 and 2000 had high diatom abundance relative to the median reference condition. Analysis of the time-series of Euclidean distance (Fig. 6A) shows that there was no long-term trend and annual values fluctuated randomly (Run's Test: $P>0.05$ ) about the time-series mean of 0.58 . Furthermore, there was no long-term trend in the annual deviation from the time-series mean (Fig. 6B).

\section{Discussion}

Previous studies of the Thau lagoon (Vaquer et al., 1996; Collos et al., 2009) have reported changes in the abundances of particular species or genera, such as Alexandrium catenella and Skeletonema costatum, and tried to interpret these in relation to natural and anthropogenic environmental change. It is, however, difficult to reach firm conclusions given the complexity of change at this level of analysis. Our approach, in the present paper, has been at the level of functional groups, and our results show the utility of the lifeform and state-space tools for analysing change in the 'balance of organisms' at this level. The Plankton Index comparison between 1987-89 and 1976 (Fig. 3) shows more dinoflagellates in 1976 compared with the 1987-89 reference, and seems to confirm the expected 'de-eutrophication' in the 1980s. Furthermore, the significant positive cross (year-to-year) correlation between PIp and annual mean DIP concentration between 1988 and 2007, suggests that the balance of organisms in the phytoplankton did respond to changes in water column DIP. However, the results also demonstrate the difficulties in clearly demonstrating the reversal of human impact resulting from coastal eutrophication. Crucially, the lack of phytoplankton data between 1977 and 1987 makes investigation of the likely cause of the observed changes difficult. 
It could be argued that the absence of a significant long-term trend in PIp after 1989 simply indicates that by 1989, water-column DIP concentrations (Fig. 2B) were already below a critical level. In other words, the lagoon had already shifted from the 1970s 'eutrophicated' regime with high DIP, to the 'moderately eutrophicated' regime that was diagnosed by Collos et al. (2009) for the period 1998-2003. Thus, although the year-to-year variation in the annual mean concentration of DIP may have contributed to the inter-annual variability in the balance of the two lifeforms as shown in the plot of medians in state-space (Fig. 5), the results of our analysis suggest that the system has remained (since 1989) in a dynamically stable regime. First, there was no long-term trend in Euclidean distance from the reference condition (Fig. 6A). Second, there was no increase in inter-annual variability about the time-series mean Euclidean distance (Fig. 6B). Based on Scheffer et al. (2009), Tett et al. (2013) suggested that such variability may serve as a proxy for inverse ecosystem resilience. Thus, the absence of long-term trends in this variability suggests there has been no change in resilience which might signal a change in the ecosystem regime.

There was much inter-annual variability in the abundance of the two lifeforms. This may in part have been due to the year-to-year variation in concentrations of DIP, but the similarity in dinoflagellate abundance in 1993 and 1976 and diatom abundance in 1997 and 2000 (Fig. 5) suggests that factors other than concentrations of DIP may be involved. It is evident that differences between the high and low DIP regimes include more than a reduction in phosphorus loading to the lagoon. Pressure variables for which we have data include increasing temperatures (Fig. 2A) which may favour the growth of picocyanobacteria (Collos et al., 2009), higher oyster biomass (Fig. 2C) which can exert a differential grazing pressure on different size classes of phytoplankton (Vaquer et al., 1996) and silicate (Fig. 2D) which appears not to have changed much (give a value) over the time-series. Unknowns include 
nitrogen loading (probably decreasing (give an estimate); see Tournoud et al., 2006), flushing rates, and the phytoplankton flora in the Mediterranean outside the lagoon.

Although the comparison between 1975-76 and 1987-89 indicates that there was a shift in the balance of the two lifeforms, this does not appear to have influenced the main human use of the lagoon, namely oyster production. In contrast, one possible consequence of the reduction in water column concentrations of DIP (in combination with the increase in water temperature) for ecosystem services is the sudden appearance of picocyanobacteria (mostly species of Synechococcus) and the saxitoxin-producing mixotrophic dinoflagellate Alexandrium catenella during the early 1990s. A. catenella counts have been included in the abundances of the dinoflagellate lifeform, and there is reliable evidence (from microscopic analyses) that A. catenella was absent or rare before this time.

According to Collos et al. (2009) Synechococcus is thought to have emerged in Thau lagoon following oligotrophication (especially the reduction in $\mathrm{P}$ ) and increasing water temperatures. During the hot summers of 2003 and 2006, when record Synechococcus cell numbers were observed, cell abundances of dominant diatom species such as Chaetoceros spp., Skeletonema spp., Leptocylindrus danicus and L. minimus were reduced by a factor of 2 to 10 relative to those during the cooler summers of 2004 or 2005 . In contrast, the diatom Ceratoneis closterium was absent in those summers. Concerning dinoflagellates, Alexandrium catenella was probably stimulated by Synechococcus as a food source (Collos et al., 2009). Other dinoflagellates such as Gyrodinium spirale and Protoperidinium bipes were absent during the hot summers. But over the time-series, the presence of Synechococcus does not seem to have displaced other phytoplankters in the lagoon (Fig. 7). 
Collos et al. (2009) hypothesized that species of picocyanobacteria were better able to exploit the low DIP and warmer water temperature conditions than other phytoplankters and may have provided an additional $\mathrm{N}$ source for the mixotrophic dinoflagellate. This and other examples of what might be considered as 'unforeseen' consequences of nutrient management, (e.g. the new harmful algal blooms in the Seto Inland Sea of Japan of Alexandrium tamarense and Gymnodinium catenatum, both able to utilize dissolved organic phosphorus, Yamamoto et al., 2002) exemplify the difficulty in attempting to manage nutrient loadings with the expectation of achieving a particular target such as minimising the risk of harmful algal blooms or returning the balance of organisms to a notional pristine state in which diatoms dominate. Interestingly, the emergence of Synechococcus spp. and Alexandrium catenella, both of which have caused major problems in the Thau lagoon in terms of economics and human health (Lilly et al., 2002; Masseret et al., 2013), does not seem to have had an impact on phytoplankton biodiversity.

Although our analysis suggests that with respect to diatoms and dinoflagellates, the system has remained in a dynamically stable regime since 1989 . The continuation of the current anthropogenic waste management policy could result in a shift to a third regime which has implications for the future productivity of the lagoon and shellfish production. Souchu et al. (1998) suggested that the 'drastic reductions in nutrient inputs could lead to a decline in primary production in the Thau lagoon'. According to La Jeunesse and Elliott (2004), there was a substantial P reservoir (>3000 tonnes) stored in the top $5 \mathrm{~cm}$ of sediment in the early 1990s with 250 tonnes mobilized each year, although a future reduction in the frequency and intensity of anoxic events (Souchu et al., 1998) is likely to influence the internal cycling of $\mathrm{P}$ and other nutrients in the lagoon. Losses of $\mathrm{P}$ from the system include $\sim 12 \mathrm{t} \mathrm{yr}^{-1}$ in harvested shellfish and an unknown amount by flushing of the lagoon by relatively 
oligotrophic Mediterranean seawater. Nevertheless, the budget presented by La Jeunesse and Elliott (2004) suggests that annual (mainly anthropogenic) loads continue to exceed annual losses and further reductions in anthropogenic loading (and perhaps increased flushing) may be required to turn the budget negative and so begin reductions in the total $\mathrm{P}$ in the system. Finally, although there has been an expensive investment in reducing anthropogenic waste input to the lagoon and numerous studies, the current scientific evidence is insufficient to evaluate the prospects for a return of the 'balance of organisms' to something like an unperturbed state. Clearly, it is highly desirable that monitoring of phytoplankton lifeforms and of the concentrations of nutrients in the lagoon continues in order to determine how phytoplankton production and the balance of species respond to further changes in the nutrient status of the Thau lagoon.

\section{Acknowledgements}

This work was supported in part by SCOR (SCOR WG 137: Global Patterns of Phytoplankton Dynamics in Coastal Ecosystems: Comparative Analysis of Time Series Observations). RG, CS and MA acknowledge the financial support of The Department of Agriculture and Rural Development in Northern Ireland and the European Fisheries Fund (Project CA/033766/11). YC, BB and EA were supported by CNRS and Ifremer.

\section{References}

Andersen, J. H., Axe, P., Backer, H., Carstensen, J., Claussen, U., Fleming-Lehtinen, V., Järvinen, M., Kaartokallio, H., Knuuttila, S., Korpinen, S., Kubiliute, A., Laamanen, M., Lysiak-Pastuszak, E., Martin, G., Murray, C., Møhlenberg, F., Nausch, G., Norkko, A., Villnäs, A., 2011. Getting the measure of eutrophication in the Baltic Sea: towards improved assessment principles and methods. Biogeochemistry 106, 137-156. 
Ærtebjerg, G., Carstensen, J., Dahl, K., Hansen, J., Nygaard, K., Rygg, B., Sørensen, K., Severinsen, G., Casartelli, S., Schrimpf, W., Schiller, C., Druon, J. N., 2001. Eutrophication in Europe's coastal waters. Topic report 7/2001, pp. European Environment Agency, Copenhagen.

Bec, B., Husseini-Ratrema, J., Collos, Y., Souchu, P., Vaquer, A., 2005. Phytoplankton seasonal dynamics in a Mediterranean coastal lagoon: emphasis on the picoeukaryote community. Journal Plankton Research 27, 881-894.

Bowman, M.J., Esias, W.E, Schnitzer, E., 1981. Tidal stirring and the distribution of phytoplankton in Long Island and Block Island Sounds. Journal of Marine Research 39, 587603.

Cloern, J.E., 2001. Our evolving conceptual model of the coastal eutrophication problem. Marine Ecology Progress Series 210, 223-253.

Collos, Y., Vaquer, A., Bibent, B., Slawyk, G., Garcia, N., Souchu, P., 1997. Variability in nitrate uptake kinetics of phytoplankton communities in a Mediterranean coastal lagoon. Estuarine Coastal Shelf Science 44, 369-375.

Collos, Y., Bec, B., Jauzein, C., Abadie, E., Laugier, T., Lautier, J., Pastoureaud, A., Souchu, P., Vaquer, A., 2009. Oligotrophication and emergence of picocyanobacteria and a toxic dinoflagellate in Thau lagoon, southern France. Journal of Sea Research 61, 68-75.

Collos, Y., Jauzein, C., Ratmaya, W., Souchu, P., Abadie, E., Vaquer, A. 2014. 
Comparing diatom and Alexandrium catenella/tamarense blooms in Thau lagoon: importance of dissolved organic nitrogen in seasonally N-limited systems. Harmful Algae 37, 84-91.

Conley, D. J., Markager, S., Andersen, J., Ellermann, T., Svendsen, L. M. (2002). Coastal eutrophication and the Danish National Aquatic Monitoring and Assessment Program. Estuaries 25, 848-861.

Costanza, R., 1992. Towards an operational definition of health. In: Costanza R, Norton B, Haskell BD (eds) Ecosystem health: new goals for environmental management. Island Press, Washington, DC, p. 239-256.

Council of European Communities, 1991. Council Directive 91/271/EEC of 21 May 1991 concerning urban waste-water treatment. Official Journal of the European Communities L135, 40-52.

De Jonge, V.N., Bakker, J.F., Van Stralen, M., 1996. Recent changes in the contributions of river Rhine and North Sea to the eutrophication of the western Dutch Wadden Sea. Netherlands Journal of Aquatic Ecology 30, 27-39.

Deslous-Paoli J-M, Souchu P, Mazouni N, Juge C, Dagault F (1998) Relations milieuressources: impact de la conchyliculture sur un environnement lagunaire méditerranéen (Thau). Oceanologica Acta 21, 831-843.

Ferreira, J.G., Andersen, J.H., Borja, A., Bricker, S.B., Camp, J., da Silva. M.C., Garcés, E., Heiskanen, A-S., Humborg,C., Ignatiades, L., Lancelot, C., Menesguen, A., Tett, P., 
Hoepffner, N., Claussen, U., 2011. Overview of eutrophication indicators to assess environmental status within the European Marine Strategy Framework Directive. Estuarine Coastal Shelf Science 93, 117-131.

Folke, C., Carpenter, S., Walker, B., Scheffer, M., Elmqvist, T., Gunderson, L., Holling, C.S., 2004. Regime shifts, resilience, and biodiversity in ecosystem management. Annual Review of Ecology, Evolution and Systematics 35, 57-581.

Gillbricht, M., 1988. Phytoplankton and nutrients in the Helgoland region. Helgolander Meeresuntersuchungen 42, 435-467.

Gowen, R.J., Mills, D.K., Trimmer, M., Nedwell, D.B., 2000. Production and its fate in two coastal regions of the Irish Sea: the influence of anthropogenic nutrients. Marine Ecology Progress Series 208, 51-64.

Gowen, R.J., Tett, P., Bresnan, E., Davidson. K., McKinney, A., Harrison, P.J., Milligan. S., Mills, D.K., Silke, J., Crooks, A.-M., 2012A. Anthropogenic nutrient enrichment and blooms of harmful micro-algae. Oceanography and Marine Biology: An Annual Review 50, 65-126.

Gowen, R.J., Tett, P., Smayda, T.J., 2012B. Phytoplankton and the balance of nature: An opinion. Estuarine Coastal Shelf Science 113, 317-323.

Holling, C.S., 1973. Resilience and stability of ecological systems. Annual Review of Ecology, Evolution and Systematics 4, 1-23. 
Hooper, D.U., Chapin, F.S., Ewel, J.J., Hector, A., Inchausti, .P, Lavorel, S., Lawton, J.H., Lodge, D.M., Loreau, M., Naeem, S., Schmid, B., Setala, H., Symstad, A.J., Vandermeer, J., Wardle, D.A., 2005. Effects of biodiversity on ecosystem functioning: A consensus of current knowledge. Ecological Monographs 75, 3-35.

Hénard, D., 1978. Production primaire d'une lagune méditerranéenne - Etang de Thau(Hérault) - année 1976. Thèse Académie de Montpellier, Université des Sciences et Techniques du Languedoc. 85 p.

Hirsch, R.M., Slack, J.R., 1984. A nonparametric trend test for seasonal data with serial dependence. Water Resources Research 20, 727-732.

Jones, K.J. Gowen, R.J. 1990. Influence of stratification and irradiance regime on summer phytoplankton composition in coastal and shelf seas of the British Isles. Estuarine, Coastal and Shelf Science 30, 557-567.

Justic, D., Rabalais, N.N., Turner, R.E., 1995. Stoichiometric nutrient balance and origin of coastal eutrophication. Marine Pollution Bulletin 30, 41-46.

La Jeunesse, I., Elliott, M., 2004. Anthropogenic regulation of the phosphorus balance in the Thau catchment-coastal lagoon system (Mediterranean Sea, France) over 24 years. Marine Pollution Bulletin 48, 679-687.

Lancelot, C., Gypens, N., Billen, G., Garnier, J., Roubeix, V., 2006. Testing an integrated river ocean mathematical tool for linking marine eutrophication to land use: The Phaeocystis- 
dominated Belgian coastal zone (Southern North Sea) over the past 50 years. Journal of Marine Systems 64, 216-228.

Lilly, E.L., Kulis, D.M., P. Gentien, P., D. M. Anderson, D.M., 2002. Paralytic shellfish poisoning toxins in France linked to human-introduced strain of Alexandrium catenella from the western Pacific: evidence from DNA and toxin analysis. Journal of Plankton Research 24, 443-452.

Mageau, M.T., Costanza, R., Ulanowicz, R.E., 1995. The development and initial testing of a quantitative assessment of ecosystem health. Ecosystem Health 1, 201-213.

Margalef, R., 1978. Life forms of phytoplankton as survival alternatives in an unstable environment. Oceanologica Acta 1, 493-509.

Masseret, E., Banack, S., Boumédiène, F., Abadie, E., Brient, L., Pernet, F., Juntas-Morales, R., Pageot, N., Metcalf, J., Cox, P., Camu, W., 2013. The French Network on ALS Clusters Detection and Investigation. Dietary BMAA Exposure in an Amyotrophic Lateral Sclerosis Cluster from Southern France. PLoS One 8, e83406.

McIntyre, A.D., 1995. Human impact on the oceans: The 1990s and beyond. Marine Pollution Bulletin 31, 147-151.

Nixon, S.W., 1995. Coastal marine eutrophication: a definition, social causes, and future concerns. Ophelia 41, 199-219. 
Picot, B., Pena, G., Casellas, C., Bondon, D., Bontoux, J., 1990. Interpretation of the seasonal-variations of nutrients in a Mediterranean lagoon - Etang-de-Thau. Hydrobiologia 207, 105-114.

Pingree, R.D., Holligan, P.M., Mardell, J., 1978. The effects of vertical stability on phytoplankton distributions in the summer on the north western European shelf. Deep Sea Research 25, 1011-1028.

Radach, G., Berg, J., Hagmeier, E., 1990. Long-term changes of the annual cycles of meteorological, hydrographic, nutrient and phytoplankton time-series at Helgoland and at Lv Elbe 1 in the German Bight. Continental Shelf Research 10, 305-328.

Rousseau, V., Lancelot, D. Cox, D. Eds., 2006. Current status of eutrophication in the Belgian Coastal Zone. Brussels, Belgian Science Policy; Presses Universitaires de Bruxelles, Bruxelles. 122 pp.

Scheffer, M., Bascompte, J., Brock, W.A., Brovkin, V., Carpenter, S.R., Dakos, V., Held, H., van Nes, E.H., Rietkerk, M., Sugihara, G., 2009. Early-warning signals for critical transitions. Nature 461, 53-59.

Scheffer, M., 2010. Foreseeing tipping points. Nature 467, 411-412.

Schaub, B.E.M., Gieskes, W.W.C., 1991. Eutrophication of the North Sea: the relation between Rhine River discharge and chlorophyll $a$ concentration in Dutch coastal waters. In: Elliott, M., Ducrotoy, J.P. (Eds.), Estuaries and Coasts: Spatial and Temporal Intercomparisons. Olsen \& Olsen, Fredensborg, Denmark, pp. 85-90. 
Souchu, P., Gasc, A., Collos, Y., Vaquer, A., Tournier, H., Bibent, B., Deslous-Paoli, J.M., 1998. Biogeochemical aspects of bottom anoxia in a Mediterranean lagoon (Thau, France). Marine Ecology Progress Series 164, 135-146.

Souchu, P., Vaquer, A., Collos, Y., Landrein, S., Deslous-Paoli, J.M., Bibent, B., 2001. Influence of shellfish farming activities on the biogeochemical composition of the water column in Thau lagoon. Marine Ecology Progress Series 218, 141-152.

Sunday, D., 2004. The Convex Hull of a 2D Point Set or Polygon. URL: softsurfer.com/Archive/algorithm_0109/algorithm_0109.htm, accessed 2014.

Tett, P., Carreira, C., Mills, D.K., van Leeuwen, S., Foden, J., Bresnan, E., Gowen, R.J., 2008. Use of a Phytoplankton Community Index to assess the health of coastal waters. ICES Journal of Marine Science 65, 1475-1482.

Tett, P., Gowen, R.J., Painting, S.J., Elliott, M., Forster, R., Mills, D.K., Bresnan, E., Capuzzo, E., Fernandes, T.F., Foden, J., Geider, R.J., Gilpin, L.C., Huxham, M., McQuattersGollop, A.L., Malcolm, S.J., Saux-Picart, S., Platt, T., Racault, M.F., Sathyendranath, S., van der Molen, J., Wilkinson, M., 2013. Framework for understanding marine ecosystem health. Marine Ecology Progress Series 494, 1-27.

Tett, P., 2014. Guide to the Plankton Index method and software. Report, 25 pp. Oban, Scotland, Scottish Association for Marine Science. Available from URL: $\underline{\text { www.sams.ac.uk/paul-tett }}$ 
Tournoud, M.-G., Payraudeau, S., Cernesson, F., Salles, C. (2006). Origins and quantification of nitrogen inputs into a coastal lagoon: Application to the Thau lagoon (France). Ecological Modelling 193, 19-33.

Vaquer, A., Troussellier, M., Courties, C., Bibent, B., 1996. Standing stock and dynamics of picophytoplankton in the Thau lagoon (northwest Mediterranean coast). Limnology Oceanography 41, 1821-1828.

Vollenweider, R.A., 1992. Coastal marine eutrophication: principles and control. Science of the Total Environment, supplement 1992 - Marine Coastal Eutrophication. 2nd International Conference on Marine Coastal Eutrophication - the Response of Marine Transitional Systems to Human Impact: Problems and Perspectives for Restoration (Bologna Italy, 21-24 Mar, 1990) pp.1-20.

von Bertalanffy, L., 1968. General Systems Theory: foundations, development, applications. George Braziller, New York NY.

Weisstein, E. W., 2006. Convex Hull. From Math World--A Wolfram Web Resource. URL: mathworld.wolfram.com/ConvexHull.html, accessed 2014.

Yamamoto, T., Ishida, M., Seiki, T., 2002. Long-term variation in phosphorus and nitrogen concentrations in the Ohta River water, Hiroshima, Japan as a major factor causing the change in phytoplankton species composition (in Japanese with English abstract). Bulletin of the Japanese Society of Fisheries Oceanography 66, 102-109. 
Table 1. A summary of the data sets used in the analysis. The annual phosphate data were derived from a minimum of 6 monthly values spread over the year.

\begin{tabular}{|c|c|c|}
\hline Variable & Time series & Notes \\
\hline $\begin{array}{l}\text { Diatom abundance } \\
\text { (cells } \mathrm{L}^{-1} \text { ) }\end{array}$ & $1975-1976$ and 1987-2009 & 1977-1985 data missing \\
\hline $\begin{array}{l}\text { Dinoflagellate } \\
\text { abundance (cells L }{ }^{-1} \text { ) }\end{array}$ & $1975-1976$ and 1987-2009 & 1977-1985 data missing \\
\hline $\begin{array}{l}\text { Annual mean water } \\
\text { temperature }\left({ }^{\circ} \mathrm{C}\right)\end{array}$ & $1972-2010$ & (1973 and 1984 missing) \\
\hline $\begin{array}{l}\text { Annual mean } \\
\text { phosphate }(\mu \mathrm{M})\end{array}$ & $1972-2007$ & $\begin{array}{l}\text { Annual values missing (only } 10 \\
\text { values between } 1987 \text { and 2007) }\end{array}$ \\
\hline $\begin{array}{l}\text { Annual Oyster stock } \\
\text { (tonnes) }\end{array}$ & 1960 and $1970-2001$ & $\begin{array}{l}\text { 1993-1997 data missing: mean } \\
\text { 1990-1992 used } \\
\text { 2002-2007 data missing: mean } \\
\text { 1999-2001 used }\end{array}$ \\
\hline
\end{tabular}


Table 2. The important (abundant) genera and species of phytoplankon contributing to the diatom and dinoflagellate lifeforms. The size ranges include chains of typical length. The reference source for taxonomic names is the World Register of Marine Species (WoRMS http://marinespecies.org/). ${ }^{1}$ previously named Cylindrotheca closterium; ${ }^{2}$ previously named Prorocentrum minimum.

\begin{tabular}{|c|c|c|}
\hline Lifeform & Species & Size range $(\mu \mathrm{m})$ \\
\hline \multirow[t]{16}{*}{ Diatom } & Asterionellopsis glacialis & $30-150$ \\
\hline & Chaetoceros spp. & $10-40$ \\
\hline & Ceratoneis closterium $^{1}$ & $80-100$ \\
\hline & Dactyliosolen fragilissimus & $30-200$ \\
\hline & Ditylum spp. & 80 \\
\hline & Guinardia striata & $30-300$ \\
\hline & Leptocylindrus danicus & 50 \\
\hline & Leptocylindrus minimus & $40-50$ \\
\hline & Nitzschia spp. & 50 \\
\hline & Pseudo-nitzschia spp. & $30-100$ \\
\hline & Rhizosolenia spp. & $10-300$ \\
\hline & Rhizosolenia pungens/setigera complex & $20-500$ \\
\hline & Skeletonema spp. & $3-20$ \\
\hline & Thalassionema nitzschioides & $30-80$ \\
\hline & Thalassionema spp. & $40-400$ \\
\hline & Thalassiosira spp. & $5-50$ \\
\hline \multicolumn{3}{|l|}{ Dinoflagellate } \\
\hline & $\begin{array}{l}\text { Alexandrium catenella/tamarense species } \\
\text { complex }\end{array}$ & $20-50$ \\
\hline & Dinophysis acuminata & 50 \\
\hline & Dinophysis sacculus & 50 \\
\hline & Gyrodinium spirale & $30-100$ \\
\hline & Heterocapsa triquetra & 35 \\
\hline & Peridinium quinquecorne & 50 \\
\hline & Prorocentrum cordatum $^{2}$ & 20 \\
\hline & Protoperidinium bipes & $30-60$ \\
\hline
\end{tabular}


Figure legends

Figure 1. A map of the Thau lagoon in southern France. Urban areas are shaded black and areas of the lagoon that are used for oyster growing are shaded grey.

Figure 2. Time-series of Thau lagoon data. A) annual mean water temperature $\left({ }^{\circ} \mathrm{C}\right)$ from 1972-2009; B) Concentrations ( $\mu \mathrm{M}$ ) of dissolved inorganic phosphate (DIP) from 1972-2007 (open circles individual sample concentrations, filled circles and dashed line annual mean concentration; C) standing stock (tonnes) of oysters (Crassostrea gigas) from 1996-2001; D) concentrations $(\mu \mathrm{M})$ of silicate from 1975-2003.

Figure 3. Diatom and dinoflagellate state space envelopes. A) For the reference period 19871989; B) The 1975-1976 data plotted into the reference envelope.

Figure 4. The time-series of the Plankton Index for phytoplankton (PIp).

Figure 5. A 2-D state space plot of the annual median values of $\log _{10}$ diatom and dinoflagellate abundance.

Figure 6. Time-series of Euclidean distance. A) The Euclidean distance of each year from the reference (1987-1989) point; B) the annual deviation from the time-series mean Euclidean distance.

Figure 7. State space plot of median monthly abundances of three lifeforms in Thau lagoon during Jun, July and August of each year. This plot adds picocyanobacterial abundance, determined by flow cytometer, to that of diatom and dinoflagellate abundances determined by microscopic analysis. Adequate flow cytometer data were available from 1992-1994 and then from 1999 onwards. The 'shadows' on the walls of the 3-D plot show the change in each pair of 2-D spaces: for example, the left-hand back wall plots the change in logarithmic median diatom abundance against the change in logarithmic median cyanobacterial abundance. Drawn using Matlab TM 'plot3' function with additional code for the shadows (available on request). 
Fig. 1

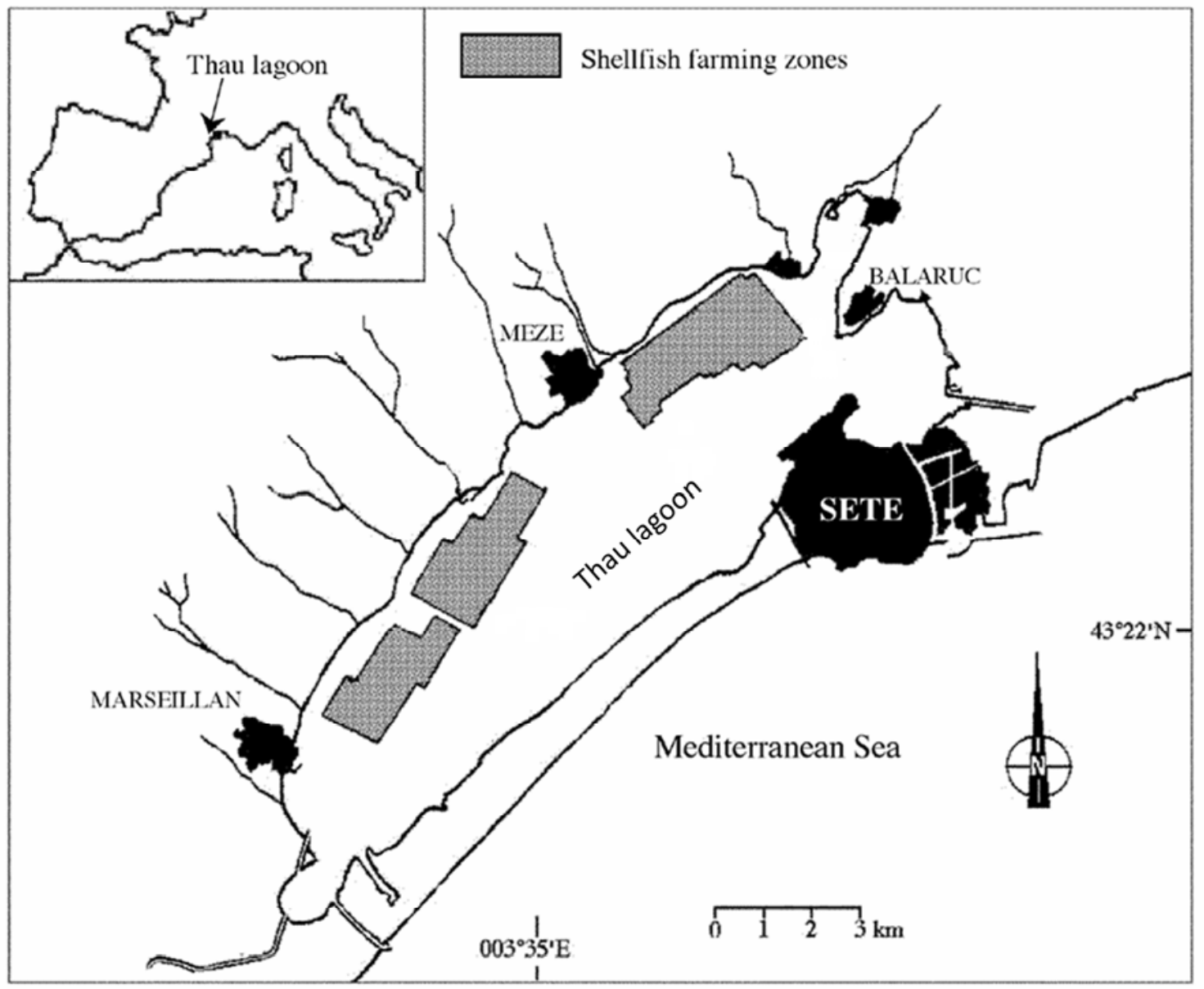


Fig. 2
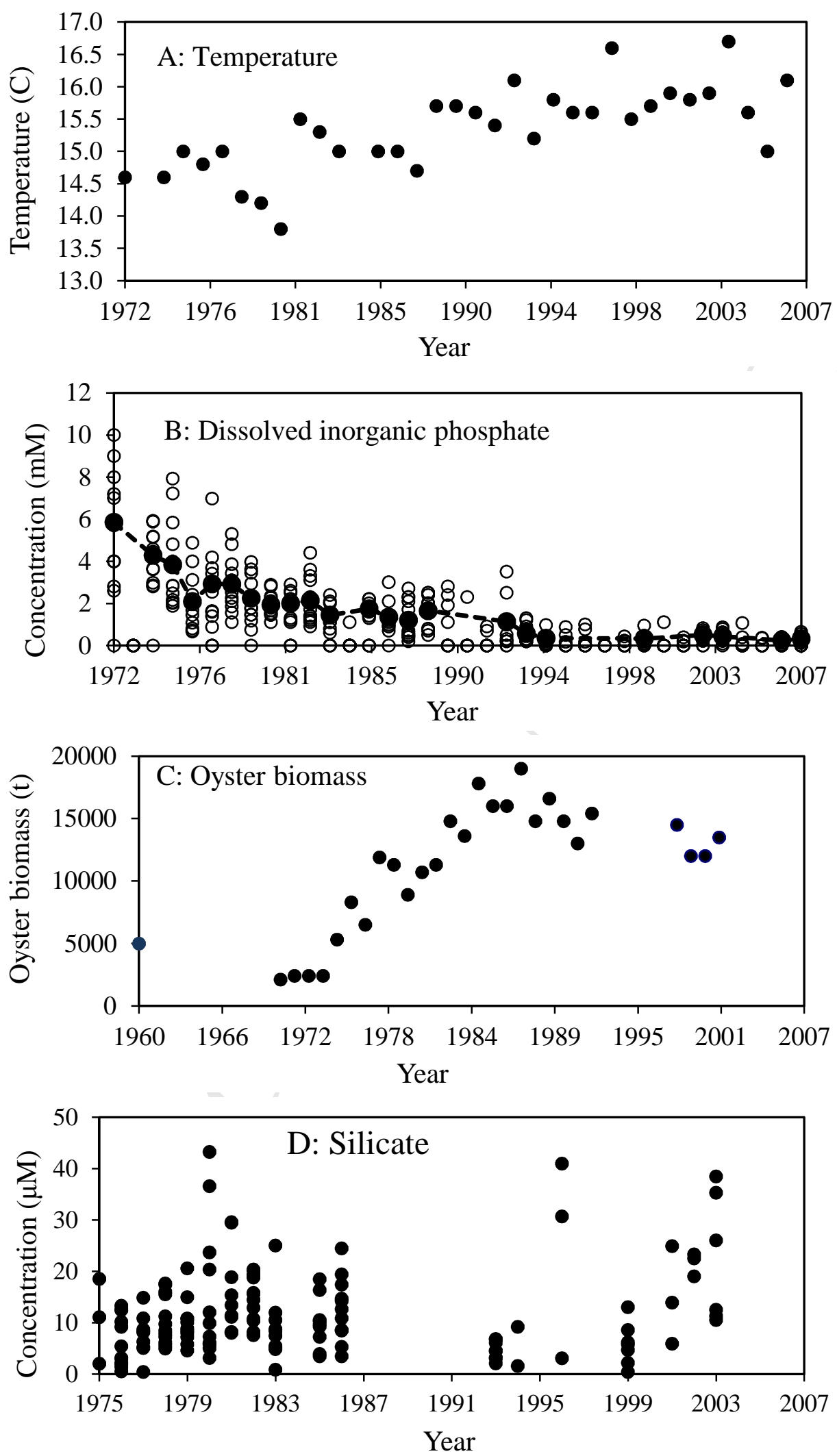
Fig 3
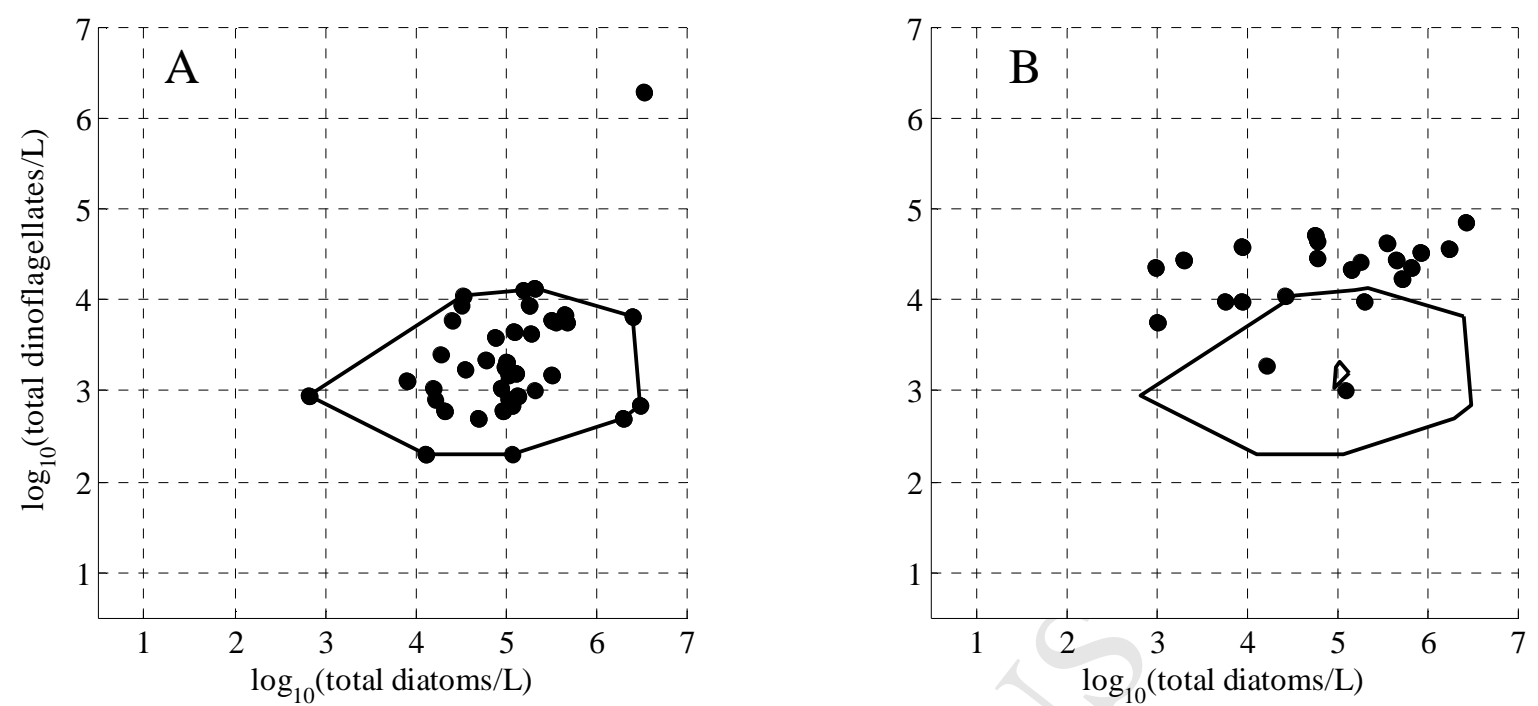

Fig 4

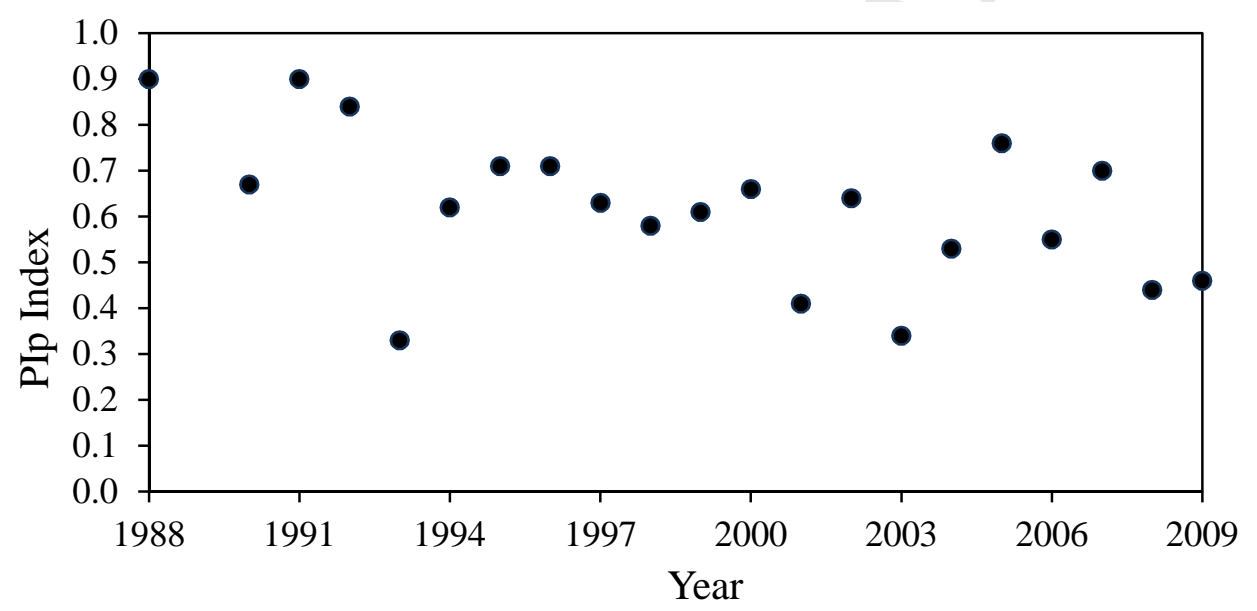


Fig 5

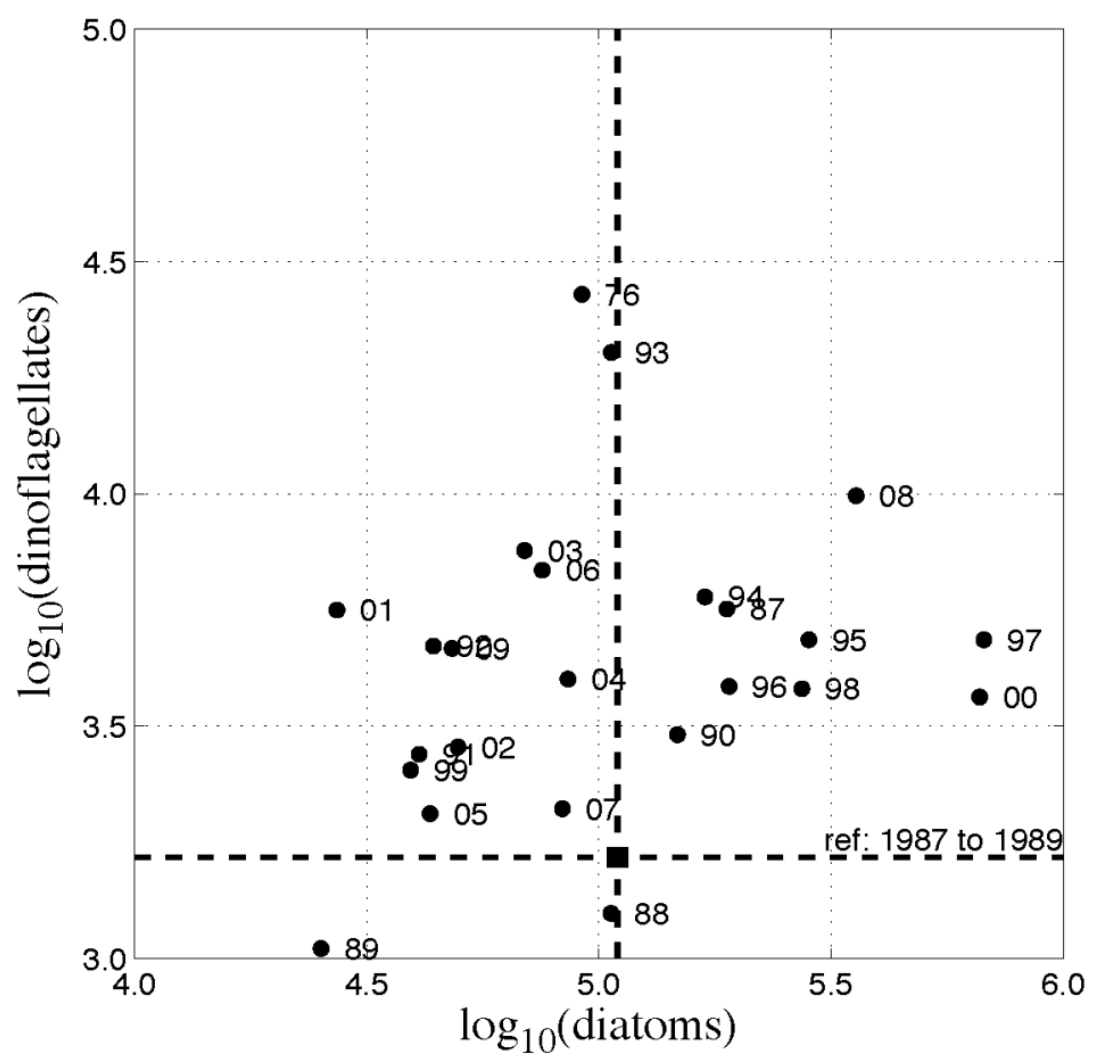


Fig 6
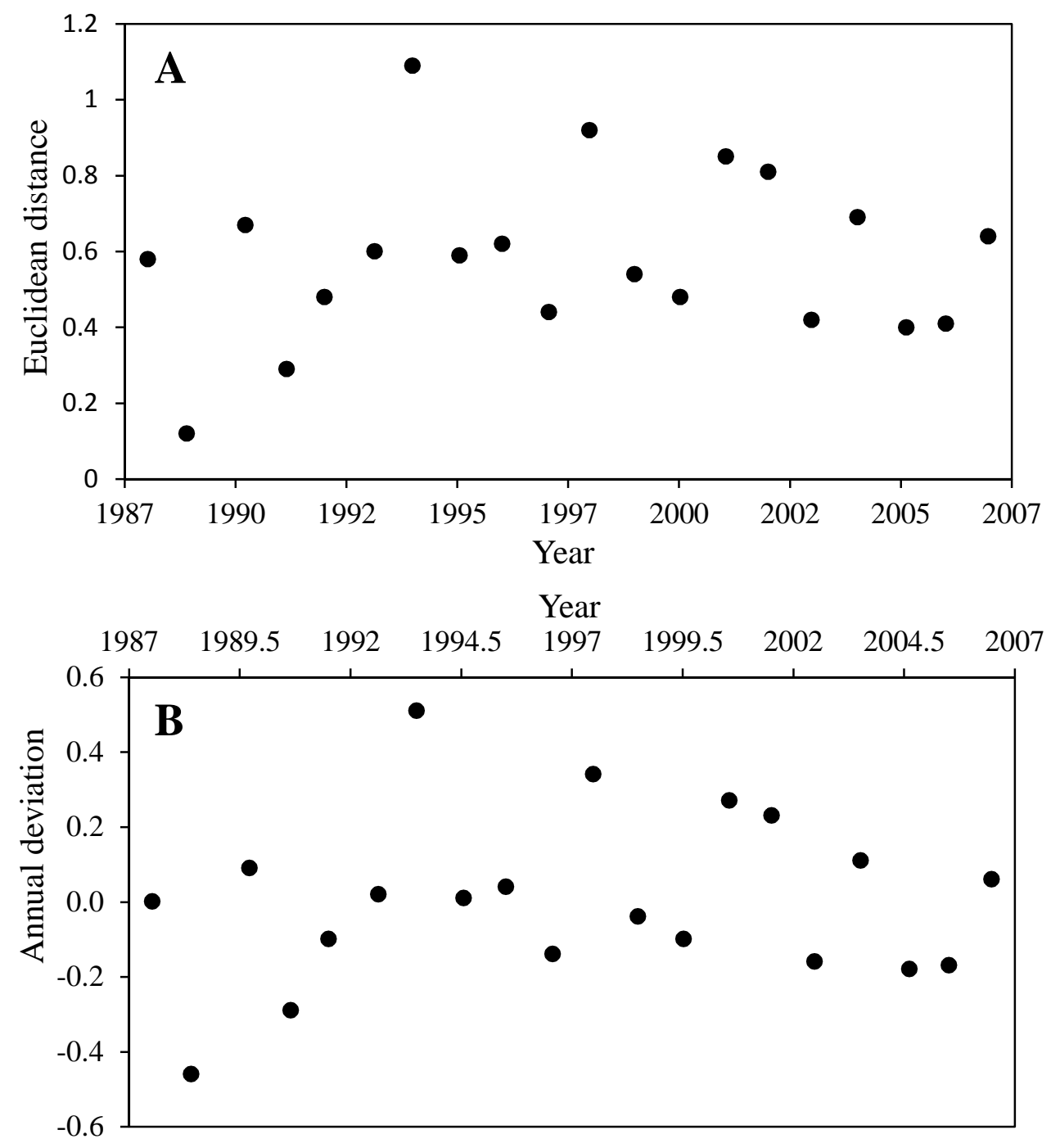
Figure 7.

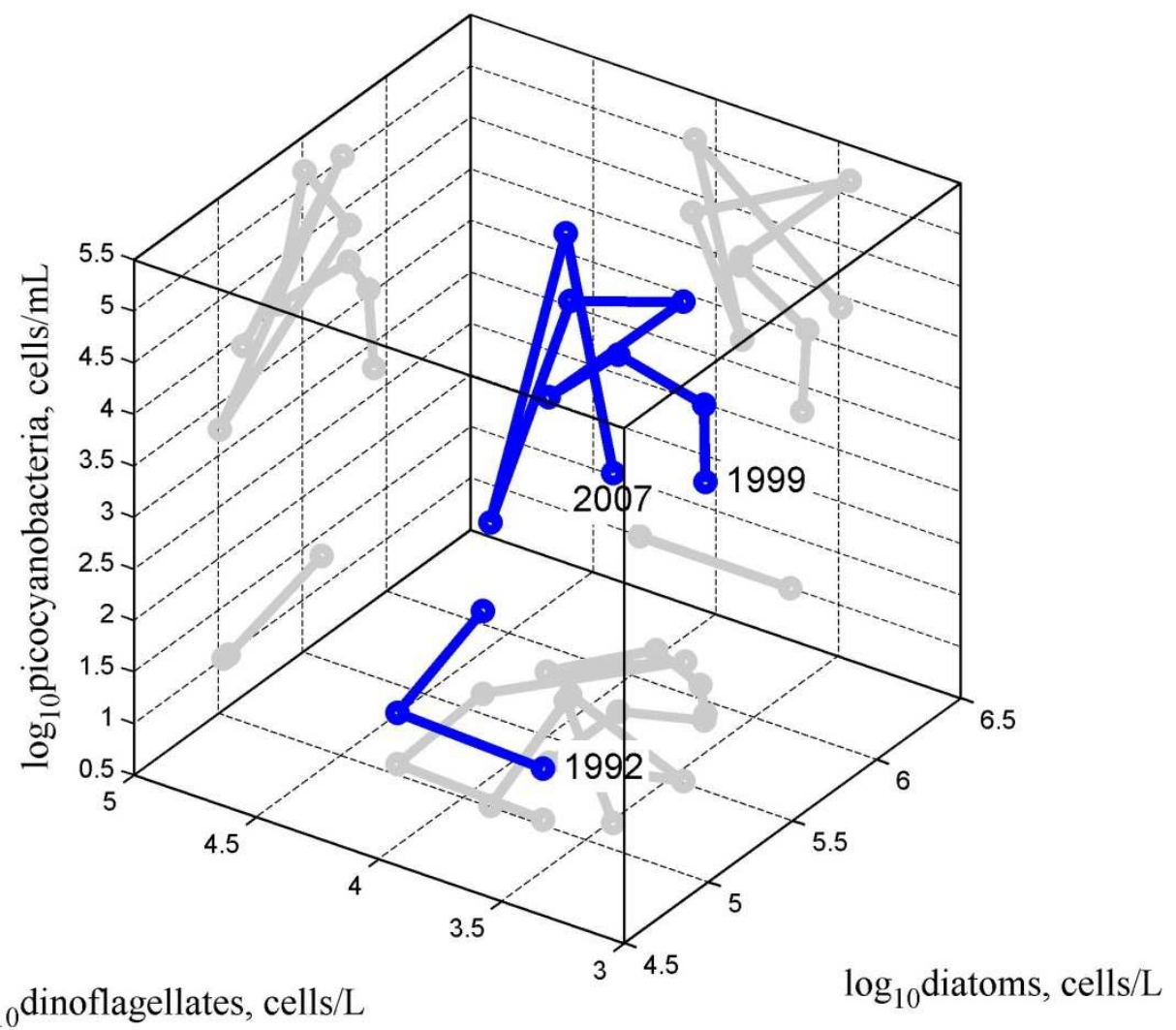

$\log _{10}$ dinoflagellates, cells/L 